\title{
LEVEL OF KNOWLEDGE OF SENIOR HIGH SCHOOL STUDENTS TO NORTH COASTAL OF JAVA CONSERVATION
}

\author{
Fahmi Arif Kurnianto $^{1}$, Bejo Apriyanto ${ }^{1}$, Elan Artono Nurdin ${ }^{1}$, Fahrudi Ahwan Ikhsan $^{1}$ \\ ${ }^{1}$ Departement of Geography Education \\ University of Jember, Indonesia \\ E-mail: fahmiarif.fkip@unej.ac.id
}

DOI: $10.19184 /$ geosi.v1i1.6192

\begin{abstract}
Article Info: Received Date $27^{\text {th }}$ November 2017, Received in revised from date $4^{\text {th }}$ December 2017, Accepted Date $7^{\text {th }}$ December 2017, Publish Date 14 ${ }^{\text {th }}$ December 2017
\end{abstract}

\begin{abstract}
The purpose of this study to analysis the influence of group investigation learning model towards the level of conservation knowledge of students in senior high school. The type of research is the quasi-experimental study with nonequivalent control group posttest only design. The subject of the study consisted of class XI Social Science are selected based on the score of Final Semester Exam on 2014-2015 teachings year that had an average of almost the same (homogeneous). The results of this study are showed significant influence of GI models on Geography level of knowledge to learn of students. It was based on the results of the Independent Sample T-Test analysis showed a p-value of 0.000 level. P-level value is smaller than $0.05(\mathrm{p}<0.05)$.
\end{abstract}

Keywords: Group Investigation Learning, Level of knowledge, conservation

\section{INTRODUCTION}

Conservation of the north coast of Java is very important given the high level of population growth. Conservation will be very meaningful if taught to students in a contextual way. This is supported by so much digital literacy and can be accessed by anyone. Abrasion becomes the main problem that must be known by students not only on cognitive, but also psychomotor and affective aspects. therefore a group investigation method is needed in order to facilitate the delivery of concepts from teacher to student effectively.

The learning model has several advantages. According to Slavin (2005: 5) model of Group Investigation (GI) has several advantages for students, among others "can develop relationships between groups, acceptance of classmates who are weak in the academic field, improve self-esteem, growing awareness to think, solve problems, ability to integrate and apply the knowledge ". GI learning will help students who are academically weak and 
embarrassed when asked the teacher directly. The students usually feel more comfortable and free when asking a question. It can help teachers to teachs the students who do not understand the material. GI learning model also teachs the students to become researchers.

This is in accordance with the opinion of Sharan (2014: 130) Group Investigation model has the advantage of it being a class community of researchers who answered questions from a problem that comes from the surrounding environment. The existence of the research community requires all students to teribat participated in the study. Therefore, the formation of small groups of five students will make all students are active in research and reduce the possibility of students who do not work in groups.

Mushodik study (2013) found that "model Group Investigation affect the critical thinking skills of students of Madrasah Aliyah Negeri 6 Jakarta". The study has similarities and differences with this research. Similarities with this study that the use of models GI and material conservation of the environment (class XI), while the difference of this study to measure the students' level of knowledge to learn geography, and research Mushodik measure critical thinking skills. According to Rusman (2012: 222) the Group Investigation model has advantages such as "developing student creativity, both individually and in groups and is seen as an active learning process, because students will learn more through the process of formation and creation". Students will have space to develop their creativity by determining topics independently. The process of formation and creation will also make it easier for students to remember for a long time and understand the material that has been learned.

According to Sumarmi (2012: 127) the Group Investigation model has several advantages as follows.

Allows students to use inquiry skills that are able to prepare students' future, giving students the opportunity to more intensively research (find and find) solving a problem, develop student leadership, allow teachers to give more individual attention to student learning needs, enable students to be more actively involved in learning, both independently and more freely in discussions, can be used in schools that carry out various types of classroom arrangements, student grouping, and scheduling, and provide opportunities to develop respect for other students who work help group progress in achieving goals.

GI learning can form students who are used to finding and finding. Students who are familiar with these two things will be better prepared to face future challenges that require more capable human resources to analyze a phenomenon. This ability is also supported by mutual respect between friends in GI learning.

According to Majid (2013: 175) the Group Investigation model has several advantages, including "improving student performance in academic tasks, students can accept 
friends who have different backgrounds, and develop students' social skills". Academic assignments can be well completed if students are given the opportunity to share teaching materials with their friends. It can only happen optimally with a small group of 5 students. The small group will be easy to do the division of tasks.

\section{METHODS}

This type of research that is quasi-experimental design with non equivalentcontrol group posttest only. The following designs were used in this study.

\begin{tabular}{ccc}
\hline Experimental Group & $\mathrm{X}$ & $\mathrm{O} 1$ \\
\hline Control Group & - & $\mathrm{O} 2$ \\
\hline
\end{tabular}

(Jacksen, 2011:153)

Description :

$\mathrm{X}=$ Learning using a model Group Investigation

- = Learning using a lecture and discussion

$\mathrm{O} 1=$ Charging a queisioner in experimental class

$\mathrm{O} 2=$ Charging a queisioner in control class

\section{RESULTS AND DISCUSSION}

The findings in this study indicate that the model group investigation significant effect on students' level of knowledge to learn the coastal conservation. Calculation t-test with SPSS 16.0 the value of the P-value for the t-test is 0,000 (Appendix 13). Judging from the level of $95 \%$, the figure is less than $0.05 \mathrm{Sig}$. The data in this study were in the form of acquisition of high school geography problem solving skills in the aspects of environmental problems. The acquisition score data of problem solving ability in the form of gainscore was determined based on the difference between the final ability score (posttest) and the initial ability score (pretest).

This score illustrates the acquisition of high school geography problem solving skills in both the control and experimental groups. Measuring the ability to solve high school geography problems is obtained through giving questions in both classes consisting of 5 items in the form of essays. The question is made according to the indicators of problem solving abilities and consulted and validated by environmental material experts. After several revisions, the questions were tested before use. Test questions include the level of difficulty, power difference, validity, and reliability. Based on the calculation of the level of difficulty, 
difference in power, validity, and reliability for the trial class, the following results are obtained.

The results showed that the model group investigation significant effect on high school students' level of knowledge to learn coastal conservation. This is evidenced by the hypothesis test. Hypothesis test results show P-value for the t-test of $0.000(0.000<0.05)$. The average value of the experimental class level of knowledge for 206, while the average value of level of knowledge control class is 163 . The results are in accordance with the opinion of Sharan (134: 2014) "investigation group to motivate students to take an active role in determining what they learned and how they study".

The results also supported by the results of previous studies, including research conducted by Tan (2004). The equation of this study with previous research the models GI effect on students' level of knowledge to learn geography. The research also has differences with previous studies. This study uses a class XI IPS SMA as a research subject, whereas previous studies using class VIII SMP as a research subject. This study learning material that is the preservation of the environment, while learning materials in research Tan namely natural resources.

The influence of the PBL model on the problem solving ability of high school geography is allegedly caused by the characteristics of the model, namely: 1) oriented to real problems; 2) real investigation; and 3) cooperation. The three characteristics of the PBL model are thought to have the advantage of increasing each indicator of problem solving ability. This is in line with the opinion of Trianto (2009) that "problem solving abilities are obtained through a process of centering on real problems".

First, this learning functioned as a place to solve real problems that occur in the surrounding environment. The presentation of real problems into learning can influence the development of the ability of high school geography problems. This is in line with the opinion of Amir (2010) "Problems provide opportunities to increase motivation in students ". Motivation will trigger students to develop patterns of thinking about the problems presented.

Giving a problem in the real context provides motivation in the form of a challenge for students to think of finding an effective solution. The motivation triggers students to develop their thinking skills. Development of thinking skills is used to examine problems that become a benchmark for the success of PBL models in achieving goals this research.

Motivation grows because every human being has curiosity. This curiosity motivates to actively build cognitive understanding in the human brain. This is in line with the opinion of Sumarmi (2012) "Mo-del PBL fosters the development of a curious attitude / further curious, objective, independent, critical, and analytical thinking both individually and 
in groups".

This is in accordance with the opinion of Slavin (2005: 5) Group Investigation model has several advantages for students, among others "can develop relationships between groups, acceptance of classmates who are weak in the academic field, improve self-esteem, growing awareness to think, solve problems, integrate and apply the knowledge capabilities ". Third, the teacher just gave GI problems early learning. The problem that the teacher namely access to mangrove forests could only use boats and frequent flooding in the village of Mojo. It requires students to analyze problems that occur. The existence of these demands could challenge students to think critically about the problems that occur and then poured in question and determine the sub-theme of the research.

It was appropriate opinion of Huda (2011: 124) Group Investigation model has several advantages for students, among others, "the students are involved in the activities of high-level thinking, such as synthesizing, summary, hypotheses, conclusions, and present a final report". Fourth, students investigate different sub-themes. GI learning in this study membagai class into five groups. Two groups investigated the mangrove forests of the physical aspect, while the three groups menginvesigasi groups of aspects of society. Subthemes of different makes high curiosity of students. The group not only focused on the sub theme diinvestigasinya, but also have to know the sub-theme investigated by other groups. Students will be more comprehensive knowledge by analyzing several sub-themes. This is in accordance with the opinion of Trianto (2007: 60 ) " learning activities should involve a variety of activities and wide-ranging skills and lead students to the types of different learning resources, either inside or outside of school " .

Additional findings in this study include group work seriously because their work will be evaluated by other groups and all the students are more active in learning. Such findings make GI learning in the classroom experiment goes well. Students are easier to be supervised and regulated by the teachers in each phase of learning . Each group is serious in doing its job because it will be evaluated on another group . Each group evaluates the clarity, attractiveness and relevance of presentation.

This is in accordance with the opinion of Pintrich, et al (1991: 10 ) "extrinsic goal orientation complements intrinsic goal orientation, and concerns the degree to the which the student perceives herself to be participating in a task for s good, such as grades, rewards, performance, evaluation byothers, and competition ". Experimental class students also looks more active in learning. No more students are sleeping, playing mobile phone, or talking with friends. The opposite occurs in the control class. Some students in the control class still looks passive. This is indicated by the students were sleeping and talking with friends. Learning 
control class that will obviously interfere with the teacher in presenting the material and passive students who will not understand the material conveyed teacher.

This is in accordance with the opinion of Rusman (2012: 222) model of Group Investigation has advantages such as "develop student creativity, either individually or in groups and is seen as an active learning process, because more students will learn through the process of formation and creation". GI model's shortcomings in this research that not all students in the group are active in asking when the stage presentation of the results is in accordance with the opinion.Hal Sumarmi (2012: 132) that GI has the following disadvantages: (1) The GI is not supported by the results of research in particular; (2) projects often involve groups of students who can afford because students are better able to direct their own learning; (3) GI sometimes requires setting different circumstances, different material types and different teaching styles; (4) the state of the class does not always give a good physical environment for small groups as between one group with another group too close to the discussion group can not run well then interfere with each other; and (5) the success of GI models depend on the student's ability to lead a group or work independently.

\section{CONCLUSION}

Based on the exposure data analysis and discussion, it can be concluded that the study on environmental preservation material with Group Investigation model a positive effect on students' level of knowledge to learn geography. The average score of students' level of knowledge to learn geography experimental class is higher than the control class . This is because the learning steps GI that requires students to search for learning resources and analyze problems independently. Activity resulted in students learning geography students' level of knowledge is high.

\section{REFERENCES}

Huda, Miftahul. 2011. Cooperative Learning. Yogyakarta: Pustaka Pelajar.

Jacksen, Sherri L. 2011. Research Methode: Moduler Approach. Stamford: Cengage Learning.

Majid, Abdul. 2013. Strategi Pembelajaran. Bandung : PT Remaja Rosdakarya.

Mushodik. 2013. Pengaruh Model Pembelajaran Group Investigation terhadap Kemampuan Berpikir Kritis Siswa Madrasah Aliyah Negeri 6 Jakarta. Tesis tidak diterbitkan. Malang: PPS Universitas Negeri Malang

Pintrich, R. Paul .Et al. 1991. A Manual for The Use of The Motivated Strategies for Learning 
Questionnaire.Ann Arbor, Michigan : National Center for Research to Improve Postsecondary Teaching and Learning.

Rusman. 2012. Model-Model Pembelajaran. Jakarta: Raja Grafindo Persada.

Sharan, Shlomo. 2014. Handbook of Cooperative Learning. New York: Teachers College Press.

Slavin, Robert E. 2005. Cooperative Learning: theory, research and practice

(N. Yusron. Terjemahan). London: Allymand Bacon. Buku asli diterbitkan tahun 2005.

Sumarmi. 2012. Model-Model Pembelajaran Geografi. Malang : Aditya Media Publishing.

Tan, Ivy Geok Chin. 2004. Effects of cooperative learning with group investigation on secondary students' achievement, level of knowledge and perceptions. Singapore: National Institute of Education.

Trianto. 2007. Model-model Pembelajaran Inovatif Berorientasi Konstruktivistik. Jakarta: Prestasi Pustaka. 